\title{
sciendo
}

\author{
EDYTA KOWALCZUK-VASILEV, RENATA KLEBANIUK, WIOLETTA SAMOLIŃSKA, \\ BOŻENA KICZOROWSKA, FILIP BIELAK
}

\section{Nutritive value of chosen special purpose dietary products}

\begin{abstract}
Introduction. Foodstuffs of special nutritional use and dietary supplements, especially in the case of sportsmen, have been known and widely used in human nutrition, nourishment, and convalescence for many years.

Aim. The aim of the study was to assess the nutritional value of two groups of special dietary formulations and, in particular, to compare the nutrient and energy content declared by producers with that revealed by the present analyses.

Material and methods. The nutritional value of two groups of formulations was assessed. The first group comprised formulations for undernourished subjects or those with contraindications to use diets with normal content of proteins and/or fats. The second group of formulations included products intended for strengthening the organism and targeted mainly at sportsmen. Samples of purchased products were analyzed for the content of basic components: dry matter, total protein, crude fat, crude ash, and structural carbohydrates. The content of carbohydrates and energy value was calculated mathematically. Additionally, the content of selected minerals (calcium, potassium, sodium, magnesium, iron, zinc, copper, manganese) was determined.

Results. The content of carbohydrates, proteins, and especially fat in the chemical composition of the analyzed products declared by the producers differed from the levels determined in this study. In the mineral composition, differences were noted in the content of macroelements, while the content of micronutrients did not differ from the declared values. Despite the differences in the composition, the declared and calculated calorific values in all formulations were similar.

Conclusions. There were differences between the declared and determined contents of nutrients in the analyzed formulations. The labels of the special-purpose industrial formulations purchased in pharmacies provided more information about their composition and nutritional value, whereas the information presented on the labels of the athlete supplements were less informative. Consumption of the supplements, in particular those dedicated for sportsmen, should be supervised by a doctor or dietitian.
\end{abstract}

Keywords: foodstuffs of special medical use, dietary supplements, food monitoring.

DOI: $10.2478 /$ pjph-2018-0003

\section{INTRODUCTION}

Foodstuffs of special nutritional use, i.e. formerly classified jointly as food for special medical purpose and supplements for the organism with demand at intense physical exercise, especially in the case of sportsmen, have been known and widely used in human nutrition, nourishment, and convalescence for many years. Their composition may substantially vary, depending on the disease, disorder, or patients' condition and age as well as the place where they receive medical help. It also depends on the purpose of administration of these supplements, i.e. as the only source of food or as supplementation of diets, and possibly on other factors. Due to the specificity of these products, their use should be effectively monitored, and reliable information on the composition, value, and indications for application should be available [1].

\footnotetext{
AIM

The aim of the study was to assess the nutritional value of two groups of special-use dietary formulations with emphasis on the nutrient and energy content declared by the producers and that shown by our analyses.
}

\section{MATERIAL AND METHODS}

The nutritional value of two groups of formulations classified formerly as foodstuffs of special nutritional use was analyzed. The choice of the formulations was prompted by the results of questionnaire surveys, carried out on the Internet forums, which regarded health, dietary nutrition, and sport as well as special-use dietary formulations indicated by the respondents. A minimum of $70 \%$ of the respondents declared consumption of the analyzed formulations. The first group comprised 3 formulations for undernourished subjects or those with contraindications to use diets with normal content of proteins and/or fats (products labeled A, B, C). These products are recommended for patients with anorexia nervosa, patients who are being prepared for surgery or diagnostic procedures of the large intestine, and for subjects with normal digestion and absorption function but requiring gavage or gastrostomy feeding, since nutrition with normal food is impossible, insufficient, or contraindicated. The products were purchased in Lublin pharmacies. The other group of formulations included products intended for strengthening the organism, mainly in sportsmen (products labeled D, E, F). The analysis was performed on the 
most popular formulations used by the respondents purchased in a sports store in Lublin. An averaged sample was prepared in accordance with PN-EN ISO 707:2009. In total, six samples were analyzed, each in triplicate. Prior to the analysis, the liquid preparations (A and B) were lyophilized. The chemical analyzes were carried out in the Laboratory of the Department of Bromatology and Nutrition Physiology and in the Central Laboratory of Agroecology of the University of Life Sciences in Lublin. The content of basic components, i.e. dry matter, total protein, crude fat, crude ash, and carbohydrates, was determined in samples of the purchased products [2]. The available carbohydrates were calculated mathematically (available carbohydrates $=$ dry matter $-($ crude $a s h+$ total protein + crude fat)) and the energy value was determined. The calorific value of the analyzed products was calculated based on Atwater's coefficients [3]. Additionally, the content of selected mineral components (calcium, potassium, sodium, magnesium, iron, zinc, copper, manganese) was determined with atomic absorption spectrometry (AAS) using a UNICAM 939/959 device.

\section{RESULTS}

All products in the group of athlete formulations were in the form of powder and exhibited similar dry matter contents (Table 1). Among the special medical supplements, only the high-energy food supplement $C$ was powdered, while the other two formulations $\mathrm{A}$ and $\mathrm{B}$ were liquid with the dry matter content of 22.4 and $31.6 \mathrm{~g} / 100 \mathrm{~g}$ of the product, respectively. Due to their different purpose, the composition of these formulations differed significantly. In their chemical composition, the contents of carbohydrates, protein, and fat declared by the producers differed from the levels determined in the present analysis, but the differences in the case of the fat and protein content were relatively large (Table 1.). The carbohydrate content determined in the analyzed products ranged from $14.8 \mathrm{~g}$ in A preparation to $96.1 \mathrm{~g}$ in $\mathrm{F}$. The declared carbohydrate content in the typically high energy carbohydrate supplements $\mathrm{C}$ and $\mathrm{E}$ formulations was slightly higher than that determined in these analyses (Table 1). In all the other formulations, the carbohydrate content declared by the manufacturer was lower than that estimated in the present laboratory analysis. Especially substantial differences were shown for A (20\%), B (12.5\%), and D $(18 \%)$ preparations.

There were also differences between the declared and determined protein content in the analyzed formulations (Table 1). The protein content shown by the present analyses of three formulations (A, B, and D) was slightly lower than that indicated by the manufacturer (from 5 to even $15 \%$ lower levels). In turn, the protein content in the $\mathrm{E}$ formulation was found to be substantially higher than the value declared on the label. In the case of two formulations $(\mathrm{C}$ and $\mathrm{F})$, where no protein or fat content was declared by the producers, the analyses detected trace protein and fat levels.

The mean content of mineral nutrients in the analyzed formulations was $0.84 \mathrm{~g} / 100 \mathrm{~g}$ of the product. The highest level of these elements was detected in the D formulation (2.67 g) (Table 1). The content of macroelements was specified only by the manufacturer of A, B, and C preparations. The highest level of sodium was detected in $\mathrm{D}$ and $\mathrm{A}$ formulations. The lowest level of sodium was determined in the $\mathrm{C}$ formulation $(2.67 \mathrm{mg})$, while a slightly higher amount, i.e. $16.4 \mathrm{mg}$, was found in E supplement. The A preparation contained the highest level of potassium $(563.3 \mathrm{mg})$, but the producer declared even a higher level $(758.7 \mathrm{mg})$. Similarly, in the case of $\mathrm{B}$, the declared content of this element was higher than that detected in the present analyses. As indicated by the present investigations (Table 2), E and F supplements had

TABLE 1. Content of nutrients in the analyzed products $[\mathrm{g} / 100 \mathrm{~g}$ of the natural product].

\begin{tabular}{|c|c|c|c|c|c|c|c|c|}
\hline \multirow{2}{*}{ Product } & \multirow{2}{*}{$\begin{array}{c}\text { Dry matter } \\
\text { Analyzed value }\end{array}$} & \multicolumn{2}{|c|}{ Available carbohydrates } & \multicolumn{2}{|c|}{ Crude protein } & \multicolumn{2}{|c|}{ Crude fat } & \multirow{2}{*}{$\begin{array}{c}\text { Ash } \\
\text { Analyzed value }\end{array}$} \\
\hline & & Declared value & Analyzed value & Declared value & Analyzed value & Declared value & Analyzed value & \\
\hline \multicolumn{9}{|c|}{ Food for special medical purpose } \\
\hline A & $22.4 \pm 0.04$ & 12.3 & $14.8 \pm 0.59$ & 4.0 & $3.81 \pm 0.15$ & 3.90 & $3.02 \pm 0.05$ & $0.73 \pm 0.02$ \\
\hline B & $31.6 \pm 0.08$ & 18.4 & $20.7 \pm 1.04$ & 6.0 & $5.10 \pm 2.29$ & 5.80 & $5.18 \pm 0.06$ & $0.62 \pm 0.02$ \\
\hline $\mathrm{C}$ & $94.9 \pm 3.89$ & 96.0 & $93.8 \pm 2.83$ & - & $0.97 \pm 0.05$ & - & $0.13 \pm 0.004$ & $0.02 \pm 0.0007$ \\
\hline \multicolumn{9}{|c|}{ Dietary supplements for athletes } \\
\hline $\mathrm{D}$ & $95.9 \pm 3.80$ & 44.2 & $52.1 \pm 2.08$ & 45.0 & $39.1 \pm 1.76$ & 2.40 & $2.03 \pm 0.04$ & $2.67 \pm 0.11$ \\
\hline $\mathrm{E}$ & $97.1 \pm 4.79$ & 80.4 & $72.5 \pm 2.92$ & 15.0 & $23.3 \pm 0.96$ & 0.80 & $0.59 \pm 0.03$ & $0.76 \pm 0.03$ \\
\hline $\mathrm{F}$ & $97.2 \pm 3.88$ & 93.0 & $96.1 \pm 4.80$ & - & $0.72 \pm 0.03$ & - & $0.07 \pm 0.002$ & $0.28 \pm 0.01$ \\
\hline
\end{tabular}

TABLE 2. Content of macroelements in the analyzed products (mg/100g of the natural product).

\begin{tabular}{|c|c|c|c|c|c|c|c|c|}
\hline \multirow{2}{*}{ Product } & \multicolumn{2}{|c|}{ Sodium } & \multicolumn{2}{|c|}{ Potassium } & \multicolumn{2}{|c|}{ Calcium } & \multicolumn{2}{|c|}{ Magnesium } \\
\hline & Declared value & Analyzed value & Declared value & Analyzed value & Declared value & Analyzed value & Declared value & Analyzed value \\
\hline \multicolumn{9}{|c|}{ Food for special medical purpose } \\
\hline A & 505.8 & 460.2 & 758.7 & 563.3 & 404.7 & 281.5 & 116.3 & 98.3 \\
\hline $\mathrm{B}$ & 337.8 & 271.6 & 596.9 & 509.1 & 341.6 & 138.8 & 86.3 & 64.9 \\
\hline $\mathrm{C}$ & 2.0 & 2.67 & - & 5.12 & - & $<$ LOD & - & $<\mathrm{LOD}$ \\
\hline \multicolumn{9}{|c|}{ Dietary supplements for athletes } \\
\hline $\mathrm{D}$ & - & 500.1 & - & 205.8 & - & 225.8 & - & 20.8 \\
\hline $\mathrm{E}$ & - & 16.4 & - & 63.2 & - & $<\mathrm{LOD}$ & - & $<\mathrm{LOD}$ \\
\hline $\mathrm{F}$ & - & 155.1 & - & 61.3 & - & 54.7 & - & 5.57 \\
\hline
\end{tabular}

Abbreviations: LOD - limit of detection 
TABLE 3. Content of microelements in the analyzed products (mg/100g of the natural product).

\begin{tabular}{|c|c|c|c|c|c|c|c|c|}
\hline \multirow{2}{*}{ Product } & \multicolumn{2}{|c|}{ Zinc } & \multicolumn{2}{|c|}{ Copper } & \multicolumn{2}{|c|}{ Iron } & \multicolumn{2}{|c|}{ Manganese } \\
\hline & Declared value & Analyzed value & Declared value & Analyzed value & Declared value & Analyzed value & Declared value & Analyzed value \\
\hline \multicolumn{9}{|c|}{ Food for special medical purpose } \\
\hline A & 6.07 & 7.9 & 0.91 & 1.05 & 8.09 & 8.43 & 1.67 & 1.35 \\
\hline B & 6.76 & 6.83 & 1.01 & 1.03 & 9.01 & 8.11 & 1.88 & 0.98 \\
\hline $\mathrm{C}$ & - & 0.25 & - & 0.06 & - & 0.24 & - & $<$ LOD \\
\hline \multicolumn{9}{|c|}{ Dietary supplements for athletes } \\
\hline $\mathrm{D}$ & - & 1.65 & - & 0.13 & - & 0.43 & - & $<\mathrm{LOD}$ \\
\hline $\mathrm{E}$ & - & 0.29 & - & 0.07 & - & 0.20 & - & $<$ LOD \\
\hline $\mathrm{F}$ & - & 0.66 & - & 0.17 & - & 0.78 & - & $<\mathrm{LOD}$ \\
\hline
\end{tabular}

Abbreviations: as in Table 2

a much lower but similar potassium level. No calcium content was found in the $\mathrm{C}$ and $\mathrm{E}$ formulations. In turn, the declared calcium content in the food for special medical purposes (A and B) was higher than that shown by the present analysis. Among the supplements for athletes, D preparation was characterized by a substantial level of this element $(225.8 \mathrm{mg})$. The highest magnesium content was found in the enteral nutrition product A, i.e. $98.30 \mathrm{mg} / 100 \mathrm{~g}$ of the product, but the manufacturer declared its higher level, i.e. $116.3 \mathrm{mg}$. The B preparation had a relatively high magnesium level (over $60 \mathrm{mg}$ ), although the declared content was by approximately $20 \mathrm{mg}$ higher than that determined in the present analysis, likewise in the case of the A formulation. The content of micronutrients, i.e. zinc, copper, iron, and manganese, was determined as well. Their content was declared only in two (A and B) of the six formulations. The present analyses did not reveal any significant differences between the analyzed and declared levels. The highest content of zinc was detected in the A (7.9 mg) and B (6.8 mg) formulations. The D supplement contained over $1 \mathrm{mg}$ of zinc, and negligible levels of this element were found in the other products. Trace levels of the other microelements were detected in the $\mathrm{C}$, $\mathrm{D}$, E, and F preparations.

Given the differences between the declared and determined composition of the analyzed products, the calorific value of the formulations was calculated (Figure 1). Both nutritional formulations from the group of special medical-use supplements, i.e. preparations A and B, had a declared calorific value of 100 and $150 \mathrm{kcal} / 100 \mathrm{~g}$, respectively. The highest calorific value was noted in the case of the high-carbohydrate preparations $\mathrm{C}(380.3 \mathrm{kcal})$ and F ( $387.8 \mathrm{kcal})$. All formulations were characterized by very similar declared and calculated caloric values, despite the differences in their composition.

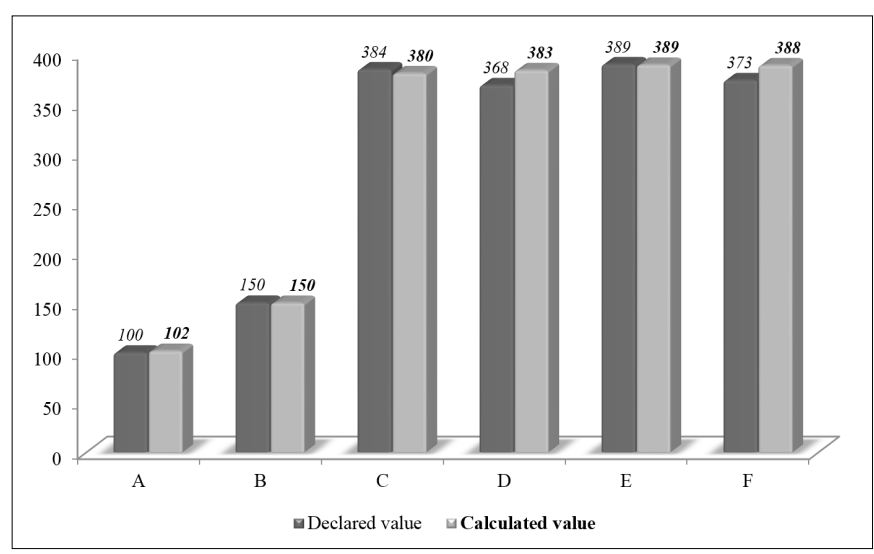

FIGURE 1. Energetic value of the analyzed products [kcal $/ 100 \mathrm{mg}$ of the product].

\section{DISCUSSION}

The analyzed groups of formulations, which were formerly classified into one group of foodstuffs of special nutritional use, have currently been assigned into two different groups of products, i.e. food for special medical purpose (dietary foodstuffs for special medical use) and dietary supplements for athletes (foodstuffs for athletes). Hence, they are targeted at different consumer groups: the products from the first group are recommended for subjects with health problems and the other group is designed for enhancement of physical performance in not only subject affected by some disease conditions but also athletes or subjects with reduced fitness. Nutritional deficiencies can contribute to development of many diseases. In the case of subjects exposed to malnutrition, there is a necessity of implementation of a diet that will supplement the deficiencies caused by long-term insufficient nutrient uptake or malabsorption of energy components, minerals, and vitamins contained in food. Foodstuffs for special medical purposes are used as part of dietary therapy of malnutrition [4-5]. Besides oral administration of high energy carbohydrate supplements (C) or high-calorie drinks, such as B, to undernourished people, enteral nutrition sometimes seems to be indispensable. In such a case, special industrial diets, such as analyzed in the study A preparation, are used. Frequently, health disorders require consumption of a greater amount of calories than the patient acknowledges. This is particularly advisable when the patient's condition is very severe or his life is threatened and the patient does not accept any food. In the malnourished patients, a supply of carbohydrates is required for maintenance of an adequate concentration of blood glucose, taking into account its small reserves. Similar to the analyzed products, the current industrial diets do not contain carbohydrates in the form of lactose or glucose but in the form of glucose polymers, which most frequently derive from starch hydrolysate. They are characterized by lower osmolality and by diarrhea prevention [4]. The analyzed formulations (e.g. C or B) have been shown to have high effectiveness by scientific research [6-7], hence their popularity among consumers.

To achieve the expected results of nutritional treatment, the formulation used for enteral or oral supply should be properly selected. Doctor or dietitian consultations and full knowledge of the composition and nutritional value of the formulations are recommended. While products for special medical purposes are most often recommended by doctors, formulations purchased in sports shops are often used without medical or dietary consultation. Detailed information provided by 
the manufacturer on the label seems even more necessary. The second group of products is designed to supplement deficiencies or introduce protein, carbohydrates, minerals, and vitamins into the diet and enrich the diet with anabolic and anti-catabolic compounds supporting muscles, accelerating regeneration, etc. Physical effort, especially in the case of competitive sports, increases the demand of the organism for a number of nutrients required for the proper function of the system [8-12]; hence, there are various types of convenience products for different groups of consumers with increased physical activity. Given the high popularity of such formulations from both the first and the second group, there is a need for monitoring their composition. Due to their different purposes, the examined preparations differed significantly in their composition and in the amount of information provided by manufacturers on the packages. The content of basic nutrients declared by the producers differed from that determined in the laboratory analyses. The carbohydrate content, especially in the A and B products, was different from that declared on the label. Noteworthy, the most similar values were detected in the typical high energy carbohydrate supplements, i.e. C and $\mathrm{F}( \pm 3 \%)$. The highest protein content was detected in the $\mathrm{D}$ formulation. The producer declared the content of this nutrient of $45 \mathrm{~g}$, but the analysis performed in this study showed a level of $39.1 \mathrm{~g} / 100 \mathrm{~g}$. Furthermore, the protein content declared by the manufacturer was declared to be the same as the carbohydrate content (carbohydrates $-44.2 \mathrm{~g} / 100 \mathrm{~g}$ of the product; protein $-45 \mathrm{~g} / 100 \mathrm{~g}$ of the product). The research showed a $5.9 \mathrm{~g}$ lower protein level and a $7.9 \mathrm{~g}$ higher carbohydrate level; hence, there was no balance between carbohydrates and protein declared by the producer in this formulation. This product is intended for subjects that want to rebuild their muscle tissue without fat gain. The producer provided information on the label about the amino acid composition, e.g. L-glutamine and glutamine peptide required for regeneration. There were substantial differences between the declared and determined protein levels in the analyzed formulations, in particular in E (55\% higher level than the declared value). Carbohydrates are the dominant component of this formulation, what was confirmed by the analysis, although there were substantial differences between the determined value and that declared by the producer. Similarly, the producer of A and B products declared a higher protein level than that determined in the analysis, but these were minor differences. Compensation of protein deficiency in the organism should be carried out carefully and gradually. Concurrent supply of nitrogen and calories in appropriate proportions is advisable [13].

The fat content slightly differed from the declared values as well. None of the formulations provided energy from fat, hence its content determined in the laboratory analysis and the values declared by the producer were negligible or zero. The fat content declared to be contained in these formulations ranged from $0 \mathrm{~g}$ in the high-carbohydrate $\mathrm{F}$ and $\mathrm{C}$ to $5.8 \mathrm{~g}$ in the $\mathrm{B}$ formulation. In all the four formulations with the fat content specified by the manufacturer, the analyzed level of this compound was substantially lower.

Such conditions as increased physical activity, biological regeneration after strain, and emaciation caused by diseases, surgeries, or starvation increase the demand for minerals in the human organism. Physical effort is associated with loss of these components via perspiration. The demand for minerals depends on the sport discipline or the present or previ- ous disease affecting the patient. The process of glycogen re-synthesis requires an increased supply of potassium to the organism, while an increased supply of magnesium determines sustenance of appropriate excitability of the muscular system. Appropriate concentrations of such components as sodium, potassium, magnesium, and calcium in the intercellular spaces ensure normal permeability of cell membranes and cell organelles, mainly in the muscle tissue [14-15].

There was no information on the package labels about the total ash content. Besides the basic macroelements required for human health and regeneration of the organism, a number of micronutrients and trace elements are important. Only the manufacturer of the A and B formulations provided the information about the content of zinc, copper, iron, and manganese on the label. The contents were similar to those determined in the laboratory analysis. The analysis showed similar levels of these elements in the products.

The calorific values of the products calculated on the basis of the chemical composition were similar to the energy values shown on the labels. The highest calorific value was determined for the high-carbohydrate formulations C (380 kcal) and $\mathrm{F}(388 \mathrm{kcal})$.

Due to the different applications of the products, the maximum energy intake was calculated according to the guidelines on the labels (Figure 2), which is especially important in the case of dietary supplementation. One dose of the $\mathrm{F}$ formulation per day should not exceed $40 \mathrm{~g}$, which provides $149 \mathrm{kcal}$. However, the manufacturer emphasized that two doses can be taken per day at an increased energy demand. In this case, the calorific value supplied will be by $298 \mathrm{kcal}$ higher than in the usual non-enriched diet. One dose of E preparation (60 g) provides $233 \mathrm{kcal}$ and $466 \mathrm{kcal}$ at the two daily doses recommended. In the case of $\mathrm{D}$ preparation, the acceptable three daily doses (one 60 -g dose provides $221 \mathrm{kcal}$ ), enrich the diet with as much as $663 \mathrm{kcal}$.

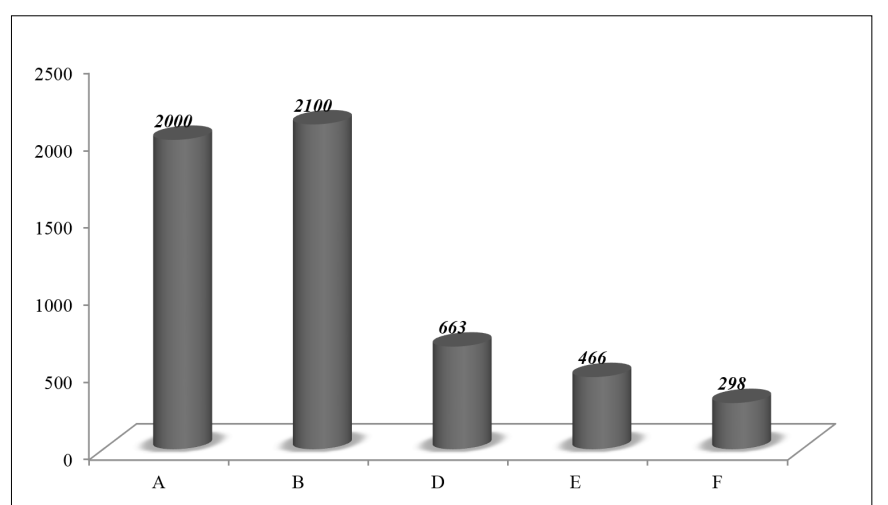

FIGURE 2. Maximum daily supply of the analyzed products [kcal] (in accordance with the guidelines on the label; upper limits of supply of the formulations).

This issue in the other group of products is slightly different. The daily dose of $\mathrm{C}$ preparation is determined by the doctor, whereas the daily dose of the $\mathrm{A}$ industrial diet, i.e. $1500-2000 \mathrm{ml}$ (at the upper limit), is $2000 \mathrm{kcal}$ per day. Importantly, the A formulation is sometimes the only source of energy for the treated patient, while the other products are used as food additives and supplementation of nutritional deficiencies. From one to four doses of the B formulation can be taken as a supplement to the diet (300-1200 kcal). As a complete diet, the intake of five to seven doses per day of $\mathrm{B}$ preparation is recommended $(1500-2100 \mathrm{kcal})$. 


\section{CONCLUSIONS}

1. The differences between the content of nutrients declared by the manufacturer and determined in the present analysis in the examined formulations were stated.

2. The special purpose dietary products purchased in pharmacies provided comprehensive data on the composition and nutritional value of the products, whereas less information was specified on the labels of the supplements for athletes.

3. Due to their high energy value and high content of some of the macronutrients, especially in the case of the supplements for athletes, consumption of the analyzed formulations should be supervised by a doctor or dietitian.

\section{REFERENCES}

1. Rozporządzenie Parlamentu Europejskiego i Rady (UE) nr 609/2013 $\mathrm{z}$ dnia 12 czerwca $2013 \mathrm{r}$.

2. AOAC. Official methods of analysis of the association of official chemists. 17th Edition. AOAC, Arlington 2011.

3. Gawęcki J. Żywienie człowieka. Podstawy nauki o żywieniu. PWN, Warszawa 1998.

4. Kotara T. Podstawy żywienia klinicznego. Warszawa: Wydawnictwo Lekarskie PZWL; 2008.

5. Jarosz. M. Praktyczny podręcznik dietetyki. Warszawa: Instytut Żywności i Żywienia; 2010.

6. Dobrzyńska E, Frydecka D. Jadłowstręt psychiczny (anorexia nervosa) - etiologia, obraz kliniczny, rozpoznawanie, leczenie. Gab Pryw. 2006;149(4):51-64.

7. Raczyńska M. Żywienie dojelitowe u dzieci leczonych chirurgicznie Przydatność preparatów firmy Ovita Nutricia. Postępy Med Klin Dosw. 1997;6(2):129-35.

8. Ziemlański Ś. Odżywki dla sportowców i innych osób obciążonych dużym wysiłkiem fizycznym. Now Med. 1996;3:39-42.

9. Hubner-Woźniak E, Lutosławska G. Podstawy biochemii wysiłku fizycznego. Warszawa: COS; 2000.

10. Bączkowicz M, Fortuna T, Ogonek J. Jakość odżywek białkowowęglowodanowych i preferencje konsumenckie osób o zwiększonej aktywności fizycznej. ŻYWNOŚĆ. Nauka. Technologia. Jakość. 2007;6 (55):268-76.

11. Stefan M, Pasiakos T, McLellan M, Lieberman HR. The effects of protein supplements on muscle mass, strength, and aerobic and anaerobic power in healthy adults: a systematic review. Sports Med. 2015;45(1):111-31.

12. Gibala MJ. Protein metabolism and endurance exercise. Sports Med. 2007;37:337-40.

13. Goulet O. Interwencje żywieniowe u niedożywionych dzieci. Stand Med. 2004;3:322-32.

14. Williams MH. Dietary supplements and sports performance: minerals J Int Soc Sports Nutr. 2005;2(1):43-9.

15. Knapik JJ, Steelman RA, Hoedebecke SS, et al. Prevalence of dietary supplement use by athletes: systematic review and meta-analysis. Sports Med. 2016;46(1):103-23.

\author{
Corresponding author \\ Dr Edyta Kowalczuk-Vasilev \\ Department of Bromatology and Nutrition Physiology \\ Institute of Animal Nutrition and Bromatology \\ University of Life Sciences in Lublin \\ 13 Akademicka St., 20-950 Lublin, Poland \\ tel. (+48 81) 4456914 \\ E-mail: edyta.kowalczuk@up.lublin.pl
}

